The Geographical Journal of Nepal

Vol. 11: 1-24, 2018

Central Department of Geography,

Tribhuvan University, Kathmandu, Nepal

\title{
Policies and institutions for disaster risk management in Nepal: A review
}

\section{Pashupati Nepal*; Narendra Raj Khanal; and Bishnu Prasad Pangali Sharma}

Central Department of Geography, Tribhuvan University, Kathmandu, Nepal

(*Corresponding Author: nepalpashupati@yahoo.com)

This paper is a review of policies for disaster risk management in Nepal and discusses the strengths, gaps and constraints of the same. Institutional and Legislative Systems (ILS) approach has been adopted focusing on three aspects: i) legal and regulatory frameworks, ii) policies and programs, and iii) organizational/institutional set-up. This paper concludes that newly endorsed Disaster Risk Reduction and Management Act (2017) can be a milestone in disaster management of Nepal not only because it has replaced about 40 years old Natural Calamity (Relief) Act, 1982 but also for the first time, it saw disaster risk management as an process focusing on different stages of disaster management cycles, preparedness, response and rehabilitation and mitigation. The provision of well-structured functional institutional set-up from the centre to local level can have positive outcome in disaster management. However, it overlooks significant aspect, such as the declaration of disaster-prone zones limiting the right of provincial disaster management committee only for recommendation to the Government of Nepal. Most of policies, strategies and legislations focused on some specific disasters such as flood, landslide, earthquake and GLOF/avalanches at national level paying less emphasis to the local level. Even now, most of the policy interventions towards different cycles of disaster risk management have laid emphasis on preparedness and response rather than to rehabilitation and mitigation. The conflicting provisions in Acts such as Water Resource Act (1992) and Building Act (1998) with Local Government Operation Act (2017) have made overlapping of their roles and responsibilities. So, the policy formulation and institutional set-up needs to be complemented by the ability and competence to operationalize the intent of the relevant acts and policies at all levels of government.

Keywords: Nepal; disaster; legislation; policy; institution; strengths; constraints 


\section{Introduction}

A combined effect of high relief and rugged topography with steep slopes, high seismicity and highly concentrated monsoon rainfall has made Nepal's fragile environment prone to varieties of hazards and disasters. Nepal stands at the top 20th most disaster prone countries in the world. The country ranks 4 th, 11 th and 30th in terms of climate change, earthquake and flood risk respectively (MoHA, 2016). Located along the Himalayan Arc, the country is highly susceptible to floods, landslides, glacial lake outburst floods and earthquakes (Petley et al., 2007; MoHA, 2011). According to the data published by MoHA (2016), during a period of 45 years (1971 to 2015), a total of 22,372 disaster events have been recorded. Hence, annually, Nepal is exposed to about 500 events of disaster. The data show that fire is one of the most recurrent hazards in Nepal. Number of the most recurrent fire incidences was 7,187 followed by flood $(3,720)$, epidemic $(3,448)$ and landslide $(3,012)$. As a result of disaster during a period of ten years $(2005$ 2015), over 700 thousand people lost their lives, over 1.4 million were injured and approximately 23 million were made homeless. In total, more than 1.5 billion people were affected and more than $\$ 1.3$ trillion economic loss was made by disasters in various ways (MoHA and DPNet-Nepal, 2015). Among the disasters, epidemic and flood and landslide hold first and second position in terms of loss of lives accounting 47.5 and 35.6 percent respectively (DWIDM, 2015).

One of the important aspects of disaster risk management (DRM) is policy and institutional provisions of the government. The success of disaster management activities largely depends on systematic formulation of policy strategies, legal provisions, institutions and its roles and responsibilities in dealing with disasters (Quarantelli, 1988; Wisner et al., 2004; UNISDR, 2009). These actions and arrangements are generally divided into four phases of a disaster management cycle, comprising of preparedness, response, relief/recovery and mitigation (Noji, 2005; Godschalk, 1991; Mileti, 1999). Neal (1997) argues that different actors, institutions, individuals and communities can be engaged within different phases of a disaster at the same time. Unsound disaster management policy and practices might increase disaster risk and disaster losses (Hasan, Akhte, Ahmed, \& Kabir, 2013). Ahmed, Moroto, Sakamoto, Haruna, Akiko (2016) also have stressed on the need of institutional strengthening for disaster risk management. Obeta (2014) has noted that in the absence of well-articulated and organized institutional structure, there arises a major obstacle to co-ordinate response activities during disaster. Fragmented responsibilities of different disaster management institutions show the lack of an effective institutional structure for disaster management and mitigation, 
particularly at the local level (Cheema, Mehmood, Imran, 2016). Farthing and Ware (2006) stressed on disaster preparedness rather than response. The shortcomings in DRM are increasingly being regarded as a consequence of weak governance and lack of political will (Williams, 2011; Jones, Oven, Wisner, 2015). Historically, public policy in disaster risk management has been heavily concentrated on response reflecting a belief that disasters are "acts of God" or "acts of Nature" - unfortunate but random calamities beyond our control. This perspective has been widely rejected by disaster researchers, who instead define disasters as interaction of physical and social phenomena (Henstra and McBean, 2005). Researchers and policy makers around the world have broadened our understanding of the physical and social variables that precipitate disasters and have identified a number of strategies to mitigate disaster losses. Internationally, there appears to be a growing consensus that a disaster management requires to move from reactive response-based disaster management to a more proactive effort to disaster risk management (Henstra and McBean, 2005). Comfort (1999) emphasizes to change the policy landscape on disaster management that relies heavily on sending assistance only after tragedy has occurred. Williams (2011) concludes that some governments have successfully adopted and implemented disaster risk management (DRM) policies, while others lag behind.

Though the Government of Nepal has made efforts to formulate and implement various legal and policy provisions to create conducive environment to disaster risk management, no significant reduction in disaster losses has been achieved yet. It is in this context that a dire necessity realized to review of the existing policies, programs and institutions for disaster risk management in order to identify the potential areas for further improvement in those provisions.

\section{Approaches and methods}

Institutional and Legislative Systems (ILS) approach (UNDP/BCPR, 2007) was adopted to analyze the existing legislations, policies/ strategies and institutional/ organizational structure for disaster risk management. ILS is a system of organizational structures, mechanisms and processes, strategies, policies, laws and regulations, resources and procedures, at all levels of administration, governing how the country manages disasters and disaster risks. The integral parts of the ILS for disaster risk management are the state, civil society and the private sector. The interaction between the components and actors of the ILS may be formal or informal. Ultimately, the effectiveness of the ILS in a country will depend on good management practices, which ensure that the individuals, 
institutions and departments involved are aware of their roles and responsibilities and have the skills to exercise them (UNDP/BCPR, 2007). For the purpose of our analysis, the elements that comprise ILS were grouped into three broad categories, such as, legal and regulatory frameworks, policies and programs and institutional/organizational structures.

During review work, first of all, online available literatures were collected from the various internet sources, such as, Google search, Research Gate, Jstor and specific journal sites-Elsevier, Journal of Integrated Disaster Risk Management, International Journal on Disaster Risk Management, Natural Hazards, British Journal of Applied Science and Technology, Economic and Political Review, Disaster Review, and others. In order to analyze the legislations on disaster risk management in Nepal, information was obtained from the website of Nepal Law Commission on www.lawcommission. gov.np. In addition, the information to review the National policies, plans and strategies on disaster risk management were gathered either in hard copy or internet portals of different institutions, such as Ministry of Home Affairs (MoHA), Department of Water Induced Disaster Management (DWIDM), Water and Energy Commission Secretariat (WECs), Ministry of Population and Environment (MoPE) and others. The literatures were searched by key words, policies, plans, strategies, act and directives, institutions on disaster risk management.

Secondly, literatures on disaster risk management were grouped into three broad categories based on the approach of Institutional and Legislative Systems (ILS), such as, legal and regulatory frameworks, policies and programs, and organizational/institutional set-up.

Thirdly, literatures on legislation, policies and strategies were analyzed by types of disaster, such as, flood and landslide, earthquake, windstorm/hailstorm and thunderbolt, GLOF/Avalanches, fire and epidemic; level of governance, such as, national, regional and local and disaster management cycles, such as, preparedness (pre-disaster), response (during disaster) and rehabilitation and mitigation (post disaster).

Finally, institutional mapping with their roles and responsibilities and linkages (both vertical and horizontal) were also made during review. Based on the review, strengths, gaps and constraints in disaster risk management were identified (Figure 1). 


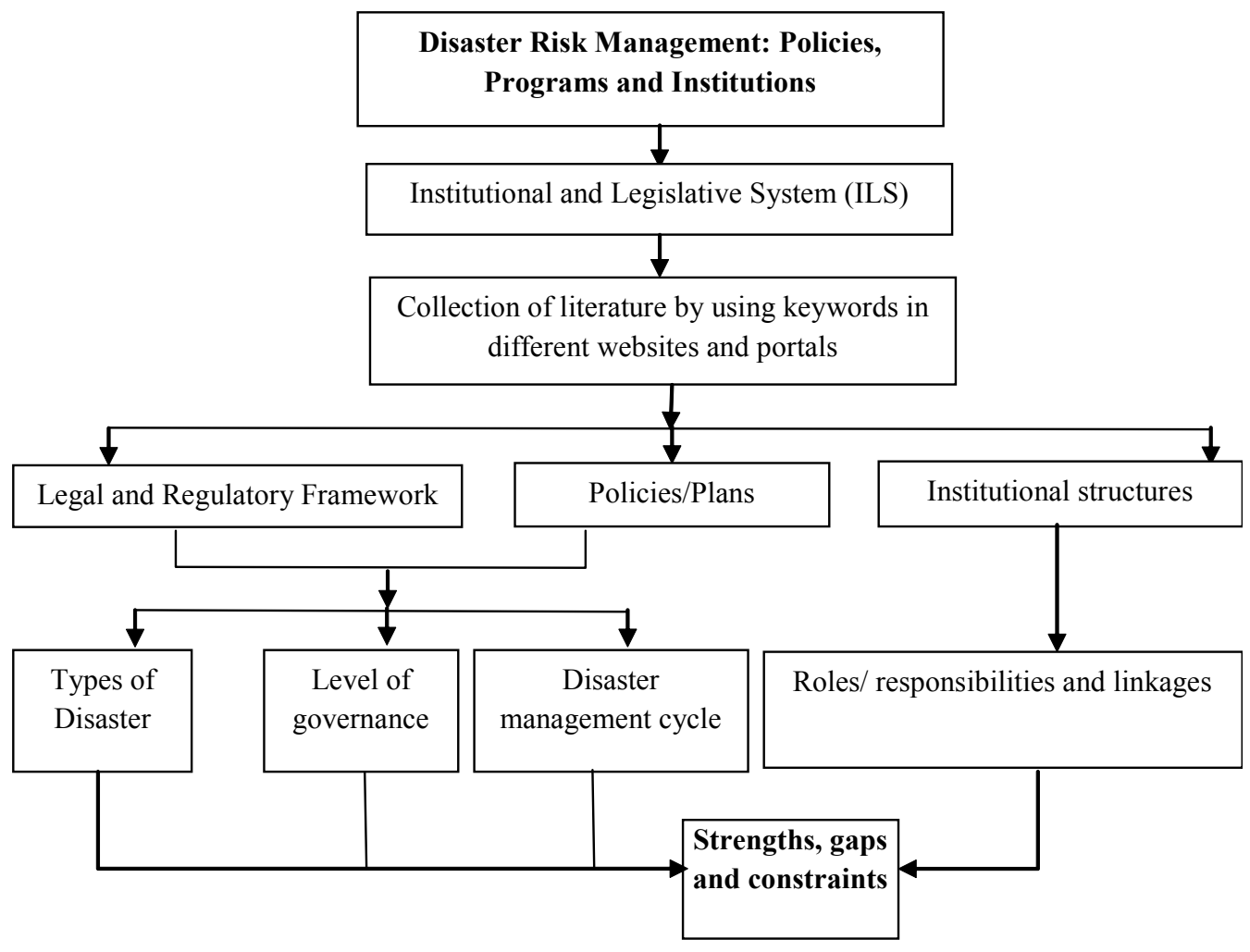

Figure 1: Methodological Framework.

\section{Results and discussion}

\section{Legal and regulatory frameworks}

Governments set out laws and regulations, which provide the basis for promoting and enforcing certain rights and obligations to groups and individuals. In the context of governance for DRM, laws set standards and objectives and assign mandates and responsibilities to different actors. Regulations and codes describe specific procedures and norms and seek to encourage or discourage certain behaviour. This rests upon the basic principle of "allowing or prohibiting activities" (Hughes, 1998) and creating incentives/disincentives (taxes, penalties, tax breaks, subsidies, grants, etc.) that will either reward or punish. The effectiveness of legislation rests upon the administrative capacity of a country but also on the acceptance and awareness of rules and norms by the populace (UNDP/BCPR, 2007). 


\section{Disaster risk management acts, codes and regulations}

Disasters in Nepal were traditionally managed on an ad-hoc basis and attended to as and when they occurred. For the first time, in 1982 the Natural Disaster Relief Act (NDRA) also known as the Natural Calamity Relief Act (NCRA) was formulated which is replaced by currently endorsed Disaster Risk Reduction and Management Act, 2017.

Soil and Watershed Conservation Act (1982) is one of the major DRM acts which has defined soil and water conservation as a function of controlling and saving landslides, floods and soil erosion. Water Resource Act (1992) focuses to minimize adverse effect on environment by way of soil erosion, flood, landslide or similar other causes. Forest Act, 1993 aims to design comprehensive structure of forest resources in Nepal from the perspective of disaster management. Environment Protection Act, 1996 has made provision of environmental impact assessment of the proposed activity before it is carried out. The Building Act (1998) has made provisions for the regulation of building construction works in order to protect building against earthquake, fire and other natural calamities. However contradict with autonomy of local body as provisioned by The Local Government Operation Act (LGOA) 2017 and low awareness among the population (NPC, 2015). Although, the Act has made local entities responsible, as the situation stands, integrated execution of concepts introduced through the Act has stalled due to absence of necessary rules, budgetary allocation and adequate guidance for the purpose (MoHA, 2009; Pradhan, 2007). Prime Minister Relief Fund Regulation (2007) has made provision of funding for rescue, assistance, medical treatment, aid to poor people, and aid for charity projects. The Constitution of Nepal (2015) has spelled out in its Directive Principles, Policies and Obligations of the State (Clause 51) about disaster management as to make advance warning, preparedness, rescue, relief and rehabilitation in order to mitigate risks from natural disasters. The constitution has given the list of concurrent powers of federation, state and local level focusing on early preparedness for, rescue, relief and rehabilitation from, natural and human-made calamities for disaster management in Schedule-7, 8 and 9 (Constitutional Assembly Secretariat, 2015). The Local Government Operation Act (LGOA) 2017, which has replaced Local Self Governance Act (LSGA) 1999, empowers local bodies to govern themselves. It recognizes that local people and local bodies are the most appropriate points of entry to meet the disaster management needs at the local level. The LGOA authorizes to undertake following functions with respect to DRR by local bodies (MoLJCAPA, 2017): 
- Local level policies, legislation, standards, plan implementation, monitoring and evaluation related to disaster management;

- Disaster preparedness and response plan, early warning system, search and rescue, advance store of relief materials, distribution and coordination at local level;

- Local embankment, river and landslide control, river management and evaluation;

- Hazard mapping and identification of settlements at risk and transformation;

- Coordination between federal, state and local level and local community organizations and coordination with private sector in order to disaster management;

- Establishment of disaster management fund and operation and utilization of resources;

- Plan formulation, implementation, monitoring and evaluation for disaster risk reduction;

- Resettlement and rehabilitation after disaster;

- Data management and study and research about local level disaster;

- Development of local emergency work operation system; and

- Implementation of community based disaster management.

Though currently promulgated this Act has made several provisions to undertake activities on disaster risk reduction at local level, we have to wait some times to achieve the outputs. The capacity building and formation of functional organs at the local level can have positive impact of the Act.

Currently endorsed Disaster Risk Reduction and Management Act, 2017 has made provision of effective disaster risk management throughout the disaster management cycle-preparedness, response and rehabilitation and mitigation (MoLJCAPA, 2017). This Act replaces the Natural Calamity Relief Act of 1982. The salient features of the Act are:

- Natural Calamity Relief Act, 1982 did not cover the broader spectrum of hazard mitigation and disaster risk management and categorization of the diversified disasters of Nepal which require different attention. Against this backdrop, this new Disaster Management Act has incorporated the whole spectrum of disaster management cycle and the diversity of disasters; 
- Disasters are defined distinctly as natural and human induced;

- This Act provides for a detailed action plan right from the central government to the district and local levels to draw implement and execute a disaster management plan. According to the act, a National Council for Disaster Management (NCDM) will function under the chairmanship of the prime minister. National Disaster Risk Reduction and Management Authority (NDRRMA) under the NCDM will be set up under Ministry to act as the focal point for disaster management functions in Nepal from formulation of appropriate strategies and plans to implementation and supervision of disaster management activities. Similarly, the state disaster management authorities will be under the Chief Ministers and the district disaster management authorities under the Chief District Officers (CDOs);

- Clarifies the role, responsibility and functions of security forces including Nepal Army;

- This Act has made provision of recommendation to the government of Nepal for the declaration of disaster-prone zones, streamlining of responsibilities and involvement of local communities.

The new Act can be considered as an umbrella Act that covers the whole spectrum of disaster risk management from preparedness phase to response, relief and rehabilitation. It has followed the new restructuring of the state and made provision of disaster risk reduction activities accordingly. The institutional set-up provisioned by this act has made effort to decentralize the role of disaster management activities, such as preparedness, response, rescue and relief to the province and district/local level. Still, this Act has made concentration of the power about disaster related policy making to the National Council making the province and district/local bodies as implementing agencies, which can be thought as major shortcoming of this Act.

The review of legislations by types of disasters, level of governance and phases of disaster management cycle is given in Table 1. 
Table1: Legislative provisions for disaster risk management

\begin{tabular}{|c|c|c|c|c|c|c|c|c|c|c|c|}
\hline \multirow[t]{2}{*}{$\begin{array}{l}\text { Regulatory } \\
\text { Framework }\end{array}$} & \multicolumn{5}{|c|}{ Types of Disaster } & \multicolumn{3}{|c|}{$\begin{array}{c}\text { Level of } \\
\text { Governance }\end{array}$} & \multicolumn{3}{|c|}{$\begin{array}{c}\text { Phases of } \\
\text { Disaster Cycle }\end{array}$} \\
\hline & 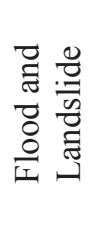 & 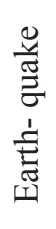 & 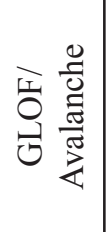 & 号 & 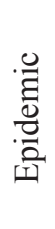 & 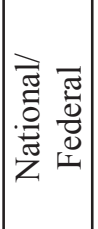 & 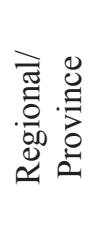 & 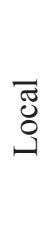 & 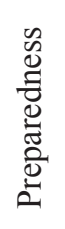 & 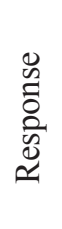 & 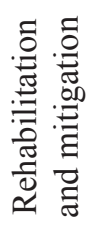 \\
\hline $\begin{array}{l}\text { Soil and Watershed } \\
\text { Conservation Act } \\
(1982)\end{array}$ & & & & & & & & & & & \\
\hline $\begin{array}{l}\text { Water Resource Act } \\
\text { (1992) }\end{array}$ & & & & & & & & & & & \\
\hline The Forest Act (1993) & & & & & & & & & & & \\
\hline $\begin{array}{l}\text { National Building Code } \\
\text { (1994) }\end{array}$ & & & & & & & & & & & \\
\hline $\begin{array}{l}\text { Environment Protection } \\
\text { Act (1996) }\end{array}$ & & & & & & & & & & & \\
\hline The Building Act (1998) & & & & & & & & & & & \\
\hline $\begin{array}{l}\text { Prime Minister Relief } \\
\text { Fund Regulation (2007) }\end{array}$ & & & & & & & & & & & \\
\hline $\begin{array}{l}\text { Constitution of Nepal } \\
(2015)\end{array}$ & & & & & & & & & & & \\
\hline $\begin{array}{l}\text { Local Government } \\
\text { Operation Act (2017) }\end{array}$ & & & & & & & & & & & \\
\hline $\begin{array}{l}\text { Disaster Risk Reduction } \\
\text { and Management Act } \\
\text { (2017) }\end{array}$ & & & & & & & & & & & \\
\hline
\end{tabular}

\section{Policies and plans}

\section{National disaster risk management policies}

One of the major policies on disaster management is National Action Plan which deals with different stages of a disaster- pre, during and post (MoHA, 1996). It has given emphasis to the hazard assessment and mapping of the recurring disasters, such as earthquake, flood, landslides, GLOF, etc. However, expected results could not be 
achieved due to inadequate resources and coordination between the concerned agencies and stakeholders (MoHA, 2009). One of the major long-term objectives of prevailing Forestry Sector Policy, 2000 is to protect land from degradation by soil erosion, floods, landslides, desertification, and other ecological disturbances. The Water Resources Strategy -2002 and the National Water Plan - 2005 have laid out the short term, medium term and long term strategies, plans for mitigation and management of water induced disasters. National Water Plan 2005 has identified different programmes, such as, Risk/ Vulnerability Mapping and Zoning, Disaster Networking and Information System, Community-level disaster
Priority 1: Understanding disaster risk.

Priority 2: Strengthening disaster risk governance to manage disaster risk.

Priority 3: Investing in disaster risk management for resilience.

Priority 4: Enhancing disaster preparedness for effective response and to "Build Back Better" in recovery, rehabilitation and reconstruction.

Box 1: Four priority areas of Sendai framework

Source: UNISDR, 2015 preparedness and others. Water Induced Disaster Management Policy-2006 has been formulated to mitigate water induced disasters and reduce loss of lives and property and to enhance institutional strengthening. International framework on disaster management, such as the Hyogo Framework for Action (HFA) 2005-2015 has played an important role in advancing the agenda for DRR (Djalante et al., 2012). National Strategy for Disaster Risk Management in Nepal (NSDRM), 2009 was implemented in line with the Hyogo Framework. It has proposed different institutional set-up to emphasis from relief to preparedness, response, rehabilitation and mitigation and mainstreaming DRR into development efforts of the country. Another Sendai Framework 2015-2030 for disaster risk management is under implementation (Box 1). As DRR a key priority for Nepal, the Sendai Framework represents a milestone achievement to ensure DRR remains on the agenda for countries over the next 15 years (UNISDR, 2015). Nepal Risk Reduction Consortium (NRRC) was set up in 2009 aiming to support the GoN to develop a long-term disaster risk management action plan (NRRC, 2013). National Adaptation Programmes of Action (NAPA), 2010, National Climate Change Policy (2011), and National Framework on Local Adaptation Plan of Action (LAPA), 2011 articulate the integration of Climate Change Adaptation (CCA) into development processes at national and local levels. The National Disaster Response Framework, 2013 (NDRF), Local Disaster Risk Management Planning Guidelines (LDRMP), 2012, National Strategic Action Plan on Search and Rescue, 2013 and others have also been designed in order to work on disaster risk management. 


\section{Integration of disaster risk management into development policies and plans}

The disaster management is a development issue that is realized by the policy makers of the country. For the first time, disaster Management issue was included in the Tenth Plan (2002-2007) of the government of Nepal. Chapter 17 emphasized on the irrigation and water induced disaster control whereas chapter 22 deals with population, environment and natural and human induced disaster management. Both chapters gave the priority on policy formulation, strengthening institutional mechanism, risk assessment, information collection and dissemination regarding the disaster management (NPC, 2002). Similarly, the Three Year Interim Plan (2007/08-2009/10) devoted separate chapter (chapter 26) on natural disaster management. The interim plan emphasizes on policy formulation, strengthening institutional mechanism, EWS, coordinated approach for DRR and linking disaster management with climate change. It was hoped that this attempt would be a landmark in the history of disaster management. The plan has listed the programs of preparedness for effective response and recovery and, risk and hazard zone mapping (NPC, 2007). The Twelfth Three Year Plan (2010/11-2012/13) set its disaster management goal to achieve goal of Hyogo Framework for Action by 2015. Long term goal of the plan was to develop disaster resilient Nepal. Moreover, mainstreaming disaster risk management, institutional and legal reform and preparedness for better response are the strategies of this plan (NPC, 2010). The Thirteenth Plan (2013/14-2015/16) directly spelled out about disaster management. This plan aims to bring disaster management issue as mainstream of development process in order to reduce its effects to human population. Therefore, the plan made three strategies to cope with disaster: i) develop appropriate legal institution for effective disaster management, ii) strengthen relation of private/local community with NGOs and INGOs for disaster management, and iii) develop early preparedness for disaster event. This plan also focuses on preparedness plan against disaster event which ultimately helps to reduce human causalities (NPC, 2013). The current Fourteenth Three Year Plan (2016/17-2018/19) has set its disaster management goal in chapter six under the section of disaster management, environment and climate change. The plan aims to reduce human, physical, economic, cultural and ecological losses due to disasters. It has made strategies for different types of disasters management, such as, earthquake, flood, landslide, epidemic and others focusing on different phases of disaster management cycles, such as, preparedness, response and rehabilitation and mitigation. It has also emphasized on governance of disaster management at national, regional and local levels (NPC, 2017).

Most of the policies, plans and strategies that deal with different types of disasters, level of governance and different stages of disaster management cycle is given in Table 2. 
Table2: Policy provisions for disaster risk management in Nepal

\begin{tabular}{|c|c|c|c|c|c|c|c|c|c|c|c|}
\hline \multirow[b]{2}{*}{ Policies, Plans and Strategies } & \multicolumn{5}{|c|}{ Types of Disaster } & \multicolumn{3}{|c|}{$\begin{array}{c}\text { Level of } \\
\text { Governance }\end{array}$} & \multicolumn{3}{|c|}{$\begin{array}{c}\text { Phases of } \\
\text { Disaster Cycle }\end{array}$} \\
\hline & 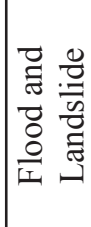 & 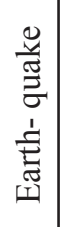 & 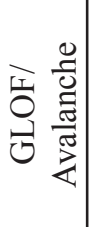 & 兽 & 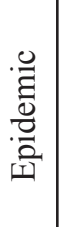 & 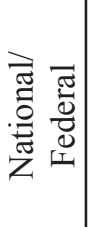 & 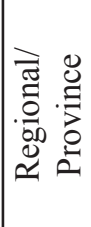 & $\bar{\Xi}$ & 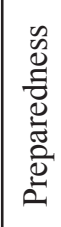 & $\left|\begin{array}{c}0 \\
0 \\
0 \\
0 \\
0 \\
0 \\
\mathscr{0} \\
\simeq\end{array}\right|$ & 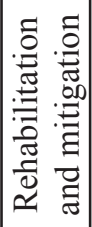 \\
\hline $\begin{array}{l}\text { National Action Plan for Disaster } \\
\text { Risk Management (1996) }\end{array}$ & & & & & & & & & & & \\
\hline Forestry Sector Policy (2000) & & & & & & & & & & & \\
\hline Water Resources Strategy (2002) & & & & & & & & & & & \\
\hline National Water Plan (2005) & & & & & & & & & & & \\
\hline $\begin{array}{l}\text { Water Induced Disaster } \\
\text { Management Policy (2006) }\end{array}$ & & & & & & & & & & & \\
\hline Tenth Plan (2002-2007) & & & & & & & & & & & \\
\hline $\begin{array}{l}\text { Three Year Interim Plan } \\
(2007 / 08-2009 / 10)\end{array}$ & & & & & & & & & & & \\
\hline $\begin{array}{l}\text { National Strategy for Disaster } \\
\text { Risk Management in Nepal } \\
\text { (NSDRM) (2009) }\end{array}$ & & & & & & & & & & & \\
\hline $\begin{array}{l}\text { The Nepal Risk Reduction } \\
\text { Consortium (NRRC) (2009) }\end{array}$ & & & & & & & & & & & \\
\hline $\begin{array}{l}\text { National Adaptation Plan of } \\
\text { Action (NAPA) (2010) }\end{array}$ & & & & & & & & & & & \\
\hline $\begin{array}{l}\text { Twelfth Three Year Plan } \\
(2010 / 11-2012 / 13)\end{array}$ & & & & & & & & & & & \\
\hline $\begin{array}{l}\text { Local Adaptation Plan of Action } \\
\text { (LAPA) (2011) }\end{array}$ & & & & & & & & & & & \\
\hline $\begin{array}{l}\text { National Climate Change Policy } \\
\text { (2011) }\end{array}$ & & & & & & & & & & & \\
\hline $\begin{array}{l}\text { National Strategic Action Plan on } \\
\text { Search and Rescue (2013) }\end{array}$ & & & & & & & & & & & \\
\hline Thirteen Plan (2013/14-2015/16) & & & & & & & & & & & \\
\hline $\begin{array}{l}\text { Fourteenth Plan (2016/17- } \\
\text { 2018/19) }\end{array}$ & & & & & & & & & & & \\
\hline $\begin{array}{l}\text { Hyogo Framework for Action } \\
\text { (HFA) (2005-2015) }\end{array}$ & & & & & & & & & & & \\
\hline Sendai Framework (2015-2030) & & & & & & & & & & & \\
\hline
\end{tabular}




\section{Institutional/organizational structure on disaster risk management}

By replacing the institutional structure of Natural Disaster Relief Act (NDRA) - 1982 and modifying the institutional structure for disaster risk management proposed by National Strategy for Disaster Management, 2009, currently endorsed Disaster Risk Reduction and Management Act, 2017 has made provisions of new institutional set-up for disaster risk management (MoLJCAPA, 2017) is shown in Figure 2:

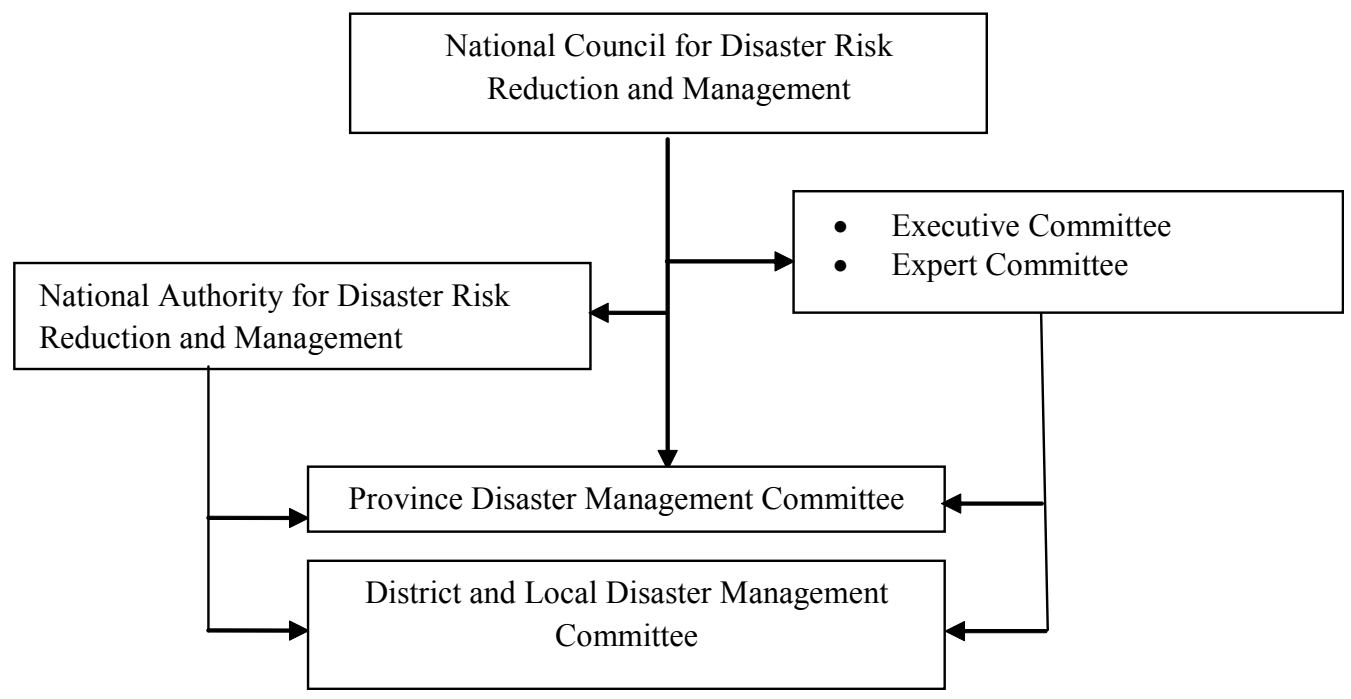

Figure 2: Institutional structure according to the Disaster Risk Reduction and Management Act - 2017.

Disaster Risk Reduction and Management Act, 2017 has made provision of set-up National Council for Disaster Risk Reduction and Management (NCDRRM) under the chairmanship of the Prime Minister as an apex body in order to disaster risk reduction and management. In order to implement policies and plans formulated by the council, there will be an executive committee under the Home Minister and expert team as well not exceeding five numbers from the different thematic areas such as, geology, environment, infrastructure and others. National Disaster Reduction and Management Authority (NDRMA) will be set-up under the Home Ministry. At Province level, there will be Province Disaster Management Committee (PDMC) under the chairmanship of chief minister. At local level, there will be District Disaster Management Committee (DDMC) and Local Disaster Management Committee (LDMC). The major rights, responsibilities and duties provisioned by this Act are given in Table 3 and institutional set-up by disaster types, level of governance and disaster management cycles is given in Table 4. 
Table 3: Institutional provisions for disaster risk management

\begin{tabular}{|c|c|c|}
\hline \multicolumn{2}{|c|}{ Institutions by Level } & Functions \\
\hline \multirow{3}{*}{$\begin{array}{l}\text { National/ } \\
\text { Federal } \\
\text { Level }\end{array}$} & $\begin{array}{l}\text { N a t i o n a } 1 \\
\text { Council for } \\
\text { Disaster Risk } \\
\text { Reductionand } \\
\text { Management } \\
\text { (NCDRRM) }\end{array}$ & $\begin{array}{l}\text { - } \quad \text { Approval of national disaster management policies and plans } \\
\text { - } \quad \text { Provide direction to executive committee and national } \\
\text { authority } \\
\text { - } \quad \text { Policy guidance to province and local level } \\
\text { - } \\
\text { Evaluation of disaster management activities }\end{array}$ \\
\hline & $\begin{array}{l}\text { Executive } \\
\text { Committee }\end{array}$ & $\begin{array}{l}\text { - Submit the national policies and plans to the council } \\
\text { - Implementation of disaster risk reduction, disaster response } \\
\text { and rehabilitation and mitigation related policies and programs } \\
\text { depending upon the limits of approved policies and plans by } \\
\text { the council } \\
\text { Implementation and approval of the disaster risk reduction } \\
\text { strategies and programs } \\
\text { - Determine the role of public, private and Non-Government } \\
\text { Organizations (NGOs) on disaster management } \\
\text { Determine the role and responsibilities of the concerned } \\
\text { ministries, departments and other institutions regarding } \\
\text { disaster management. } \\
\text { Institutional capacity building of national, province and } \\
\text { district and local level on disaster management. } \\
\text { Incorporate disaster management related courses from the } \\
\text { school level to higher education. } \\
\text { Vulnerability assessment and hazard mapping }\end{array}$ \\
\hline & $\begin{array}{c}\text { National } \\
\text { Disaster } \\
\text { Reduction } \\
\text { and } \\
\text { Management } \\
\text { Authority } \\
\text { (NDRMA) }\end{array}$ & $\begin{array}{l}\text { - Implement the plans, programs and decisions approved from } \\
\text { the council and executive committee } \\
\text { Work as resource centre for disaster reduction and } \\
\text { management } \\
\text { - Study and conduct research in the issues about causes and } \\
\text { mitigation measures of landslide, flood, earthquake, climate } \\
\text { change, land-use change and other different hazards and } \\
\text { disasters. } \\
\text { Provide financial and technical assistance to province and } \\
\text { local level to prepare periodic plans related to disaster } \\
\text { management. } \\
\text { Involve private, NGOs and local community in disaster } \\
\text { management } \\
\text { Formation of search and rescue team to national, province } \\
\text { and local level and build their capacities to handle disasters } \\
\text { Mobilize security forces, search and rescue team. Awareness } \\
\text { creation about disaster management }\end{array}$ \\
\hline
\end{tabular}




\begin{tabular}{|c|c|c|}
\hline $\begin{array}{l}\text { Province/ } \\
\text { State } \\
\text { Level }\end{array}$ & $\begin{array}{l}\text { Province } \\
\text { Disaster } \\
\text { Management } \\
\text { Committee } \\
\text { (PDMC) }\end{array}$ & $\begin{array}{l}\text { - Implement the disaster related medium term and short term } \\
\text { policies, plans and programs in the province level based on } \\
\text { the approved national policies and plans from the council. } \\
\text { - } \text { Facilitation and coordination for effectiveness of the } \\
\text { preparedness activities of the local disaster management } \\
\text { committee } \\
\text { - Coordination with national, province and local level to make } \\
\text { - } \text { Makfectiveness of the activities about search and rescue } \\
\text { - } \text { Management of drinking water, food, clothes and medicines } \\
\text { in disaster affected areas } \\
\text { - } \text { Recommend to GoN for declaration of emergency in disaster } \\
\text { affected areas } \\
\text { - } \text { Eove the unsafe people to the safe places } \\
\text { and installation of Early Warning System (EWS) }\end{array}$ \\
\hline \multirow{2}{*}{$\begin{array}{l}\text { Local } \\
\text { Level }\end{array}$} & $\begin{array}{l}\text { District } \\
\text { Disaster } \\
\text { Management } \\
\text { Committee } \\
\text { (DDMC) }\end{array}$ & $\begin{array}{l}\text { - Implement the policies, plans and programs approved by } \\
\text { - } \quad \text { Preparation and implementation of Disaster Response Plan of } \\
\text { the district } \\
\text { - } \quad \text { Mobilize emergency operation centre (EOC) of the district } \\
\text { - } \text { Conduct search and rescue works in the affected areas } \\
\text { - Management of dead bodies due to disasters } \\
\text { - Management of drinking water, food, clothes and medicines } \\
\text { - } \text { in disaster affected areas } \\
\text { - } \quad \text { Coordination of national and international assistance during } \\
\text { - } \text { disaster } \\
\text { Information flow about disasters }\end{array}$ \\
\hline & $\begin{array}{l}\text { LocalDisaster } \\
\text { Management } \\
\text { Committ e e } \\
\text { (LDMC). }\end{array}$ & 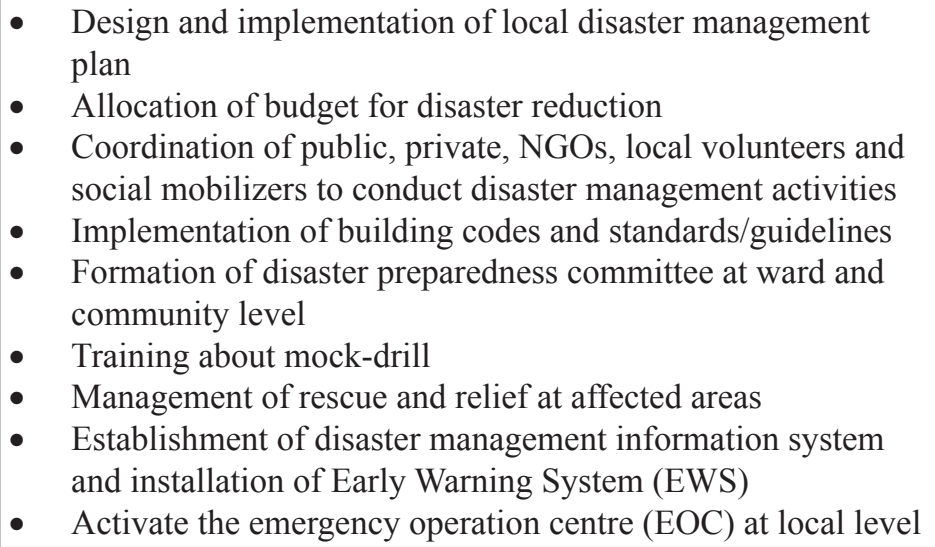 \\
\hline
\end{tabular}

Source: Disaster Risk Reduction and Management Act- 2017. 
Table 4: Institutional provisions for different types of disaster

\begin{tabular}{|c|c|c|c|c|c|c|c|c|c|c|c|}
\hline \multirow[b]{2}{*}{ Name of the Institution } & \multicolumn{5}{|c|}{ Types of Disaster } & \multicolumn{3}{|c|}{$\begin{array}{c}\text { Level of } \\
\text { Governance }\end{array}$} & \multicolumn{3}{|c|}{$\begin{array}{c}\text { Phases of } \\
\text { Disaster Cycle }\end{array}$} \\
\hline & 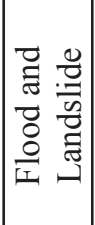 & 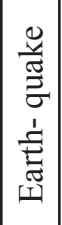 & 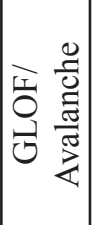 & 号 & 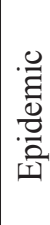 & 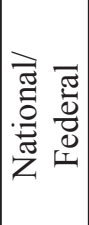 & 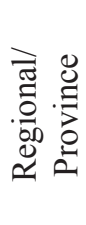 & శ్రే & 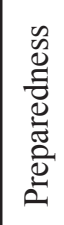 & 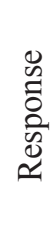 & 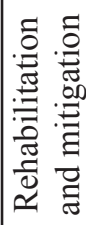 \\
\hline $\begin{array}{l}\text { National Council for Disast } \\
\text { Risk Reduction and Manage } \\
\text { (NCDRRM) }\end{array}$ & & & & & & & & & & & \\
\hline $\begin{array}{l}\text { National Disaster Reduction } \\
\text { and Management Authority } \\
\text { (NDRMA) }\end{array}$ & & & & & & & & & & & \\
\hline $\begin{array}{l}\text { Province disaster managem } \\
\text { Committee }\end{array}$ & & & & & & & & & & & \\
\hline $\begin{array}{l}\text { District and Local Disaster } \\
\text { Management Committee }\end{array}$ & & & & & & & & & & & \\
\hline
\end{tabular}

Source: Disaster Risk Reduction and Management Act- 2017.

As Nepal is declared as federal state, proper workable coordination among the National level, Province level, District Level and Local Level agencies or authorities is required to perform disaster management activities. Nepal had the Natural Calamity Relief Act of 1982. However, it did not cover the broader spectrum of disaster risk management and also could not give the different attentions for different types of disasters. Against this backdrop, this new Act has incorporated the whole phases of disaster management cycles and the diversity of disasters. This Act has promoted proactive DRR focused approach of disaster management. It will be a good opportunity to engage collectively the relevant government agencies, non-government, private sector and development partners for practical implementation of the provisions of the New DRM Act for building disaster resilience.

\section{Gaps and constraints}

Even the new Act, Disaster Risk Reduction and Management Act (2017), the coordination of Disaster Risk Management goes to the Home Ministry as the Act provides the executive roles. The shortcomings of this arrangement can be the exposure to greater political instability at the highest level of government. It can result in a lack of recognition by other ministries and less opportunities to take initiatives vis-à-vis other ministries. 
It is necessary to educate and raise the awareness of the communities in order to disaster management. The role of community-organized groups can play a crucial role in disseminating disaster related information. Studies have shown that the crucial role of these grassroots organizations in educating the citizens of Nepal (ADPC, 2010; IFRC, 2011). In the Seti Landslide Dam Outburst Flood (LDOF), 2012, lack of awareness on the part of communities has been observed. In this flood, when the landslide occurred and blocked the river, the downstream flow dropped drastically which was a good indicator of early warning. However, the community did not have the awareness to react appropriately.

Water Resource Act (1992) has made provision of ownership of the water resources to the central government. On the other hand, Local Government Operation Act (2017) has made the local bodies the owner of the local resources. In the same way, Department of Urban Development and Building Construction (DUDBC) has full responsibilities under the Building Act (1998) for development and updating of the National Building Code. The Act specifies requirements for approval prior to construction of larger buildings. But the implementation of the National Building Code and other requirements of the Building Act lie with local government. It is not clear that whether Municipalities actually had an obligation to implement these provisions or they are established under the Local Government Operation Act makes them independent from this obligation. With many new municipalities being declared in Nepal, the issue of urban planning and building code implementation is a pressing concern (Jones, Oven, Aryal and Manyena, 2014). Building code implementation and land use planning are keys to effective earthquake risk reduction. In Nepal, this responsibility falls to the Department of Urban Development and Building Construction within the Ministry of Urban Development for private buildings over seven-storey and all government buildings. But the responsibility of construction of schools goes to the Ministry of Education and the private sector. Likewise, construction of some hospitals are the responsibility of the Ministry of Health and the private sector; and local government buildings which fall under the Ministry of Federal Affairs and Local Development (MoFALD). This is an uncomfortable situation because effective building code implementation would require this department to preside over the municipalities, but municipalities currently fall within the remit of MoFALD. This is one area where institutional incoherence is evident.

The regional nature of the disasters requires a regional approach to the solution. During the Koshi Flood, 2008, in the absence of a trans-boundary disaster management framework, the response was poorly coordinated. Likewise, during the Jure landslide event of August 2014 in Sindhupalchwok, the Sun Koshi River was blocked for several days (Khanal and Gurung, 2014). A great concern emerged from the Indian side regarding the status 
of the landslide and the likelihood of an outburst flood. This example shows that disaster risk management could be an entry point for immediate regional cooperation. This will create trust, which can be a basis for future cooperation for maximizing benefits (Nepal and Shrestha, 2015).

\section{Conclusions}

Most of the disaster policies in Nepal emphasize on response and relief efforts, with relatively less strategic focus on preparedness and mitigation. Regulatory and legislative gaps and institutional weaknesses have persisted in terms of mitigating disaster risk. In this context, currently ratified Disaster Risk Reduction and Management Act (2017) can be a milestone in disaster management of Nepal because it has replaced about 40 years old Natural Calamity (Relief) Act, 1982 and for the first time it saw disaster management as an process focusing on different stages of disaster management cycles, preparedness, response and rehabilitation and mitigation and has classified disaster as natural and human-induced. The provision of well-structured functional institutional set-up from the centre to local level, it may still take some time and effort to change the institutional inertia at national and provincial and local levels. Most of the policies, plans and strategies have laid emphasis on flood and landslide followed by earthquake and GLOF/avalanches and treated as centrally rather than locally. Most of them have paid less attention towards rehabilitation and mitigation. Conflicts between different Acts, such as, Water Resource Act (1992) and Building Act (1998) with Local Government Operation Act 2017 can be considered as major obstacles in practical implementation of the disaster management act. Until now, the sole responsibilities of implementing disaster management activities goes to the Ministry of Home Affairs (MoHA) leaving other ministries as passive partners. This can create incoherence between and among the ministries and departments. It is in this context, the policy formulation and institutional set-up alone does not give much expected out-put unless they are complemented by the ability and competence to operationalize the intent of the relevant acts and policies, i.e., preparing, responding, rehabilitating and mitigating the consequences in the event of disaster.

\section{References}

ADPC (2010). Nepal hazard risk assessment. Bangkok, Thailand: Asian Disaster Preparedness Center.

Ahmed, Tofayel, Moroto, Haruna, Sakamoto, Maiko, Haruna, \& Matsuyama Akiko (2016). Exploring implementation gaps between policy and practice for disaster 
P. Nepal; N. R. Khanal; and B. P. Pangali Sharma / The Geographical Journal of Nepal Vol. 11: 1-24, 2018

management in Bangladesh. Journal of Integrated Disaster Risk Management, 6(2): 79-102.

ADRC (2014). Disaster management institution and system in Nepal. Kathmandu: Nepal: Asian Disaster Reduction Center.

Cheema, Abdur Rehman, Abid Mehmood \& Imran, Muhammad. (2016). Learning from the past: Analysis of disaster management structures, policies and institutions in Pakistan. Disaster Prevention and Management, 25(4): 449-463.

Comfort, L., Wisner, B., Cutter, S., Pulwarty, R., Hewitt, K., Oliver-Smith, A., Wiener, J., Fordham, M., Peacock, W. \& Kringold, F. (1999). Reframing disaster policy: The global evolution of vulnerable communities. Environmental Hazards, 1: $39-44$.

Constitutional Assembly Secretariat (2015). Constitution of Nepal. Kathmandu: Nepal Law Commission..

Djalante, R., Thomalla, F., Sinapoy, M.S., \& Carnegie, M. (2012). Building resilience to natural hazards in Indonesia: Progress and challenges in implementing the Hyogo Framework for Action. Nat. Hazards, (62): 779-803.

DWIDM (2006). Water induced disaster management policy 2006. Kathmandu: Department of Water Induced Disaster Management.

DWIDM (2015). Loss of lives by different types of disasters in Nepal. Disaster Review, 2014, $22: 8$.

Farthing D.W., Ware M. (2006). When it comes to mapping developing countries, disaster preparedness is better than disaster response. Retrieved from http/ www.researchgate.net/publication/235747321, on July 15. 2015.

Godschalk, D. R. (1991). Disaster mitigation and hazard management. In T.E. Drabek and G.J. Hoetmer (eds), Emergency Management: Principles and Practice for Local Government. Washington, DC: International City Management Association.

GoN (1999). Local self governance act, 1999. Kathmandu: Government of Nepal.

GoN/MoE (2010). National Adaption Programme of Action (NAPA) to Climate Change. Kathmandu: Government of Nepal, Ministry of Environment.

GoN/MoE (2011). National framework on local adaptation plans for action (LAPA). Kathmandu: Government of Nepal, Ministry of Environment. 
Hasan, Zaheed; Akhte, Sabihar, Ahmed, Shammi, \& Kabir, Alamgir (2013). Challenges of integrating disaster risk management and climate change adaptation policies at the national level: Bangladesh as a case. Global Journal of Human Social Science Geography, Geo-Sciences, Environmental Disaster Management, 13 (4):54-65.

Henstra, Dan \& McBean, Gordon (2005). Canadian disaster management policy: Moving toward a paradigm shift? Canadian Public Policy / Analyse de Politiques, 31 (3): 303-318. Retrieved from http://www.jstor.org/ on January 5, 2016.

HMG (1993). Forest Act, 1993. Kathmandu: HMG.

HMG (1997). Environment Protection Act, 1997. Kathmandu: HMG

HMG/ MoPPW (2004). Irrigation Policy 2004. Kathmandu: His Majesty of Government/ Ministry of Physical Planning and Works.

HMG/MoFSC (2000). Forestry Sector Policy, 2000. Kathmandu: HMG/ Ministry of Forest and Soil Conservation.

Hughes, Owen E. (1998). Public management \& administration: An introduction. Second Edition. London: Macmillan.

IFRC (2011). Analysis of legislation related to disaster risk reduction in Nepal. Geneva, Switzerland: International Federation of Red Cross and Red Crescent Societies.

IFRC (2014). Nepal and India: Landslides and floods. Information Bulletin. International Federation of Red Cross and Red Crescent Societies (IFRC); Available from https://www.ifrc.org/docs/Appeals/rpts14/IBNPIN1s030814. pdf on December 21, 2014.

Jones, S. J, Oven, K., Aryal, K., \& Manyena, B. (2014). Governance struggles and policy processes: A case study from Nepal. Geo-forum, 57:78-90.

Jones, Samantha, Oven, Katie, J., \& Wisner, Ben (2015). A comparison of the governance landscape of earthquake risk reduction in Nepal and the Indian State of Bihar. International Journal of Disaster risk management, 15:29-42. Retrieved from www.elsevier.com/locate/ijdrr on 6 November, 2015. 
P. Nepal; N. R. Khanal; and B. P. Pangali Sharma / The Geographical Journal of Nepal Vol. 11: 1-24, 2018

Khanal, N. R., \& Gurung, D. R. (2014). ICIMOD Rapid Field Investigation: Jure Landslide Dam Site Jure, Sindhupalchowk District, Nepal. Kathmandu: International Centre for Integrated Mountain Development.

Mileti, D. S. (1999). Disasters by Design: A Reassessment of Natural Hazards in the United States. Washington, DC: Joseph Henry Press.

MoHA (2011). Nepal: National progress report on the implementation of the Hyogo Framework for Action (2009-2011). GoN/Ministry of Home Affairs, Disaster Management Section. Retrieved from <http://www.preventionweb. net/ nfiles/15615_npl_National HFA progress_2009-11.pdf $>$ on 17.03.15.

MoHA (2011). Nepal Disaster Report, 2011. Kathmandu: Ministry of Home Affairs.

MoHA (1996). National action plan on disaster management in Nepal. Kathmandu: His Majesty's Government / Ministry of Home Affairs.

MoHA (2008). Disaster Country profile. Kathmandu: Ministry of Home Affairs.

MoHA (2009). Nepal Disaster Report, 2009. Kathmandu: Ministry of Home Affairs.

MoHA (1982). Natural calamity (relief) act, 1982. Kathmandu: Ministry of Home Affairs.

MoHA (2005) Disaster Reduction and Management in Nepal Issues and Prospects. A National Report of Nepal Presented to the World Conference on Disaster Reduction Kobe, Japan, January 18-22, 2005. Kathmandu: Ministry of Home Affairs.

MoHA (2009). National Strategy for Disaster Risk Management, 2009. Kathmandu: Ministry of Home Affairs.

MoHA (2010 b). Draft of Disaster Management Bill 2010. Kathmandu: Ministry of Home Affairs.

MoHA (2013). National Disaster Response Framework (NDRF) 2013. Kathmandu: Ministry of Home Affairs.

MoHA \& DPNet-Nepal (2013). Nepal Disaster Report 2013. Kathmandu: Ministry of Home Affairs and Disaster Preparedness Network -Nepal.

MoHA \& DPNet-Nepal (2015). Nepal disaster report 2015. Kathmandu: Ministry of Home Affairs (MoHA) and Disaster Preparedness Network-Nepal. 
P. Nepal; N. R. Khanal; and B. P. Pangali Sharma / The Geographical Journal of Nepal Vol. 11: 1-24, 2018

MoHA (2016). Disaster Risk Reduction in Nepal:Achievements, Challenges and Ways Forward. National Position Paper for the AMCDRR 2016, 2-5 November, New Delhi, India. Kathmandu: Ministry of home affairs.

MoLJCAPA (2017). Disaster risk reduction and management act 2017. Kathmandu: Ministry of Law, Justice and Parliamentary Affairs.

Neal, D.M. (1997) Reconsidering the phases of disaster, International Journal of Mass Emergencies and Disasters, 15(2) :239-264.

Nepal, S., \& Shrestha, A. B. (2015). The Himalayan waters: Complex challenges and regional solutions. Kathmandu: International Centre for Integrated Mountain Development.

Noji, E.K. (2005), Disasters: Introduction and state of the art. Epidemiologic Reviews, 27 (1): 3-8.

NPC (2002). Tenth plan, 2002-2007. Kathmandu: National Planning Commission.

NPC (2007). Three Years interim plan (2007-2010). Kathmandu: National Planning Commission.

NPC (2010). Twelfth three year plan (2010/11-2012/13). Kathmandu: National Planning Commission.

NPC (2013). Thirteenth plan (2013/14-2015/16). Kathmandu: National Planning Commission.

NPC (2015). Nepal earthquake 2015: Post Disaster Needs Assessment. Vol. B: Sector reports. Kathmandu: National Planning Commission.

NPC (2017). Fourteenth plan (2017/18-2019/20). Kathmandu: National Planning Commission.

NRCS (2011). International Disaster Response Law (IDRL) in Nepal. Kathmandu: Nepal Red Cross Society.

NRRC (2011). Flagship Programmes. Kathmandu: Nepal Risk Reduction Consortium.

NRRC (2013). Nepal Risk Reduction Consortium Flagship Programmes. Kathmandu: Nepal Risk Reduction Consortium.

Obeta, Michael Chukwuma (2014). Institutional approach to flood disaster management in Nigeria: Need for a preparedness plan. British Journal of Applied Science \& Technology, 4(33): 4575-4590. www.sciencedomain.org 
Petley, D.N., Hearn, G.J., Hart, A., Rosser, N.J., Oven, K.J., \& Mitchell, W.A. (2007). Trends in landslide occurrence in Nepal. Natural Hazards, (43): 23-34.

Pradhan, B. K. (2007). Disaster preparedness fornatural hazards: Currentstatus in Nepal. Kathmandu: International Centre for Integrated Mountain Development.

Quarantelli, E.L. (1988). Disaster crisis management: A summary of research findings. Journal of Management Studies, 25(4):373-385.

Shrestha, Rasmi K., Rhodante, Ahlers, Marloes, Bakker, \& Joyeeta, Gupta (2010). Institutional dysfunction and challenges in flood control: A Case Study of the Kosi Flood 2008. Economic and Political Weekly, 45 (2):45-53 Retrieved from http://www.jstor.org/ on 08-02-2016 05:54.

UNDP/BCPR (2007). A global review: UNDP support to institutional and legislative systems for disaster risk management. New York: United Nations Development Programme/Bureau of Crisis Prevention and Recovery.

UNDP/BCPR (2007). Governance for disaster risk management 'how to' guide. A conference draft. New York: United Nations Development Program/ Bureau for Crisis Prevention and Recovery.

UNISDR (2007a). Hyogo framework for action 2005-2015. Building the Resilience of Nations and Communities to Disasters. Extract from the final report of the World Conference on Disaster Reduction (A/CONF.206/6). United Nations Office for Disaster Reduction (UNISDR). <http://www.unisdr.org/files/1037_ hyogoframeworkforactionenglish.pdf $>$ (accessed January 5, 2016).

UNISDR (2009). UNISDR terminology on disaster risk reduction. United Nations International Strategy for Disaster Reduction (UNISDR), Geneva and Islamabad, available at: www.unisdr.org/eng/library/UNISDR-terminology-2009-eng.pdf (accessed 19 September 2009).

UNISDR (2014). Progress and challenges in disaster risk management: A contribution towards the development of policy indicators for the Post-2015 framework on disaster risk management. Geneva, Switzerland: The United Nations Office for Disaster Risk Management.

UNISDR (2015). Sendai framework for disaster risk management 2015-2030. Geneva, Switzerland: United Nations Office for Disaster risk management. 
P. Nepal; N. R. Khanal; and B. P. Pangali Sharma / The Geographical Journal of Nepal Vol. 11: 1-24, 2018

UN (2005). Report on the world conference on disaster reduction. Kobe, Hyogo, Japan: United Nations.

Williams, G. (2011). Study on disaster risk reduction, decentralisation and political economy. Global Assessment Report on Disaster Risk Reduction (GAR). $<$ http:// www.preventionweb.net/english/hyogo/gar/2011/en/bgdocs/Williams_2011. pdf $>$ (accessed 04.07.14).

Wisner, B., Blaikie, P., Cannon, T., \& Davis, I. (2004). At risk: Natural hazards, peoples' vulnerabilities and disasters. London: Routledge.

www.disasterpreparedness.icimod.org

www.lawcommission.com

WWW.moha.gov.np/uploads/newsFiles/6487 